\title{
6 From the protection of marriage to the defence of equality
}

\author{
The Finnish debate over the sexual \\ autonomy of wives
}

\author{
Riikka Kotanen
}

\section{Introduction}

Intimate relationships are the most common context for rape (UN Women, 2011), and there is a strong correlation between physical and sexual violence within them: the majority of victims of intimate partner violence (IPV) are also victims of rape within the same relationship (e.g. Black et al., 2011). Wider societal awareness of rape in marriage rose gradually alongside second-wave feminism, the growing criticism of violence against women and the lack of state intervention in both the private sphere and in intimate relations (Gavey, 2005). The first empirical research on the topic, conducted in the United States in the early 1980s, revealed the extent of the problem and described its characteristics as well as giving voice to the victims (Russel, 1982; Finkelhorn \& Yllö, 1985). Feminist activism and pioneering research raised awareness, which consequently led a number of countries to criminalise rape in marriage during the 1980s and early 1990s. Nevertheless, marital rape, or rape in intimate relationships more generally, is still legally and socially condoned in many countries: more than 2.6 billion women still live in nations that have not criminalised rape in marriage, either legislatively or judicially, ${ }^{1}$ or where a marital exemption exists allowing husbands to have sexual intercourse regardless of their wives' consent (UN Women, 2011).

The intertwined effects of the social and legal inequality of genders have manifested differently in legislation regulating sex crimes. From the perspective of wives, the most persistent restrictions on their sexual autonomy, in general, relate to the position of women in society. More specifically, these restrictions are connected to the unequal legal position of men and women in the context of marriage resulting in the subordination of wives. The change in legal thinking concerning wives' sexual autonomy is thus connected to the shift in meanings and norms attached to marriage as a social institution. According to a wealth of international comparisons, the Nordic countries rank highest in gender equality from the social and legal perspective. Historically, gender equality was recognised significantly earlier in Nordic countries than elsewhere in Europe, which included the modernisation of legislation (e.g. Pylkkänen, 2009). For example, in 1906, Finnish women were among the first to acquire the vote, and they 
were the first to be able to run for Parliament. Moreover, the marriage acts were completely transformed in the Nordic countries from 1909 to 1929. This was a joint Nordic process in which women's movement took an active part (Melby et al., 2006).

The process resulted in progressive modern regulations that emancipated married women, particularly economically; sexuality and issues related to personal integrity, however, were not addressed within the context of the marriage acts (Melby et al., 2006). But a concurrent process of the revision concerning sexual crimes did take place, where statutes based on religious moral perceptions, such as illicit intercourse, were abolished (e.g. Kotanen, 2010). The revised marriage legislation aimed for a union of equal partners both seen as responsible, independent individuals contributing to the shared marital economy. Moreover, securing women and children economically, even in cases of divorce, was seen as important in terms of ensuring a thriving population; equality was a key feature in the struggle against social problems. According to Melby, Pylkkänen, Rosenbeck and Carlsson Wetterberg (2006), the Nordic marriage reform indicated the growing influence of state responsibility and intervention - the rise of the Nordic welfare state - at the expense of religious views. Yet, they point out that the normative climate in Finland at the time was more conservative than in other Nordic countries, especially in the liberalisation of divorce.

Given the early equalisation in legislation in terms of gender, it comes as no surprise that the Nordic countries were also in the forefront of criminalising rape in marriage. Sweden and Denmark removed a marital exemption from their respective legislations in the early 1960s. In Norway, although its legislation lacked a marital exemption, a 1974 Supreme Court verdict confirmed that rape in marriage was a criminal act. In other Western countries, the wider wave of legal changes securing wives' sexual autonomy started later, during the 1980s (e.g. Yllö, 2016). In Europe, the development was spurred on by the European Parliament's Resolution on Violence against Women of 1986, which urged member states to criminalise rape in marriage. The Finnish case is an interesting exception in the Nordic context: the marital exemption was removed from the Criminal Act in 1994. Finland was following several European jurisdictions that had repealed the marital exemption or had explicitly criminalised rape in marriage in the late 1980s and the early 1990s.

Although Finland provided for the legal equality of spouses within marriage in the 1920s, gaining physical and sexual autonomy took a surprisingly long time, especially in comparison to the other Nordic countries. Using this inconsistency as a starting point, this chapter explores this particular delay in the Finnish legislation by analysing (1) how and why wives' sexual autonomy was rejected in the early $1970 \mathrm{~s}$, (2) what motivated the later criminalisation of marital rape in 1994, and (3) what kind of role the interaction between law and wider societal values played during the legal processes analysed in this chapter (cf. Pylkkänen, 2009). 


\section{The Nordic myth of equality and wives' sexual autonomy}

Because of the Nordic countries' strong egalitarian tendencies, gender equality there has traditionally been understood as a fairly symmetrical balance between men and women (e.g. Pylkkänen, 2009; Julkunen, 2010). Formal equality has long been a valued social and legal element, and the genders have been generally perceived as 'different but equal'. This has been explained by the Nordic emphasis on mutual solidarity and individual responsibility to the state and to the universalism and inclusiveness of the Nordic welfare state model (Nousiainen \& Niemi-Kiesiläinen, 2001). Despite its gender neutrality, the Nordic welfare state has largely been characterised as women-friendly (Hernes, 1987), particularly because the welfare state has created a social environment where the boundaries between public and private have been comparatively easy to cross for women. This has allowed them to enjoy economic independence, resulting in widespread possibilities for self-determination in most areas of life (Kantola, 2006).

Feminist scholars have pointed out a certain lack of polarisation in terms of gender-related issues in the Nordic countries, particularly in comparison to social class. According to this feminist critique, the hegemony of sameness visible, for example, in the way gender differences are often downplayed in the Nordic countries - has created a myth of equality. Such a myth captures situations where equality is understood in society as something that is already realised and complete, as opposed to a future, yet-to-be achieved goal (Nousiainen \& Niemi-Kiesiläinen, 2001). Among the negative consequences of this myth are equality-blind spots such as personal integrity, sexuality and antidiscrimination issues, all of which garnered wider attention only in the late 20th century (Pylkkänen, 2009). The case study from Finland presented in the current chapter highlights not just the above-mentioned difficulties in acknowledging gender differences and women's bodily rights but also the importance of equality as a collective concept and value.

The historical acceptability of marital rape can be explained by a combination of socio-legal ideologies and attitudes to marriage, sexuality and gender inequality. Globally, the widespread acceptance of marital rape has been based on three overlapping ways of reasoning. The first of these justifications is the idea of women as property, particularly in terms of sexuality (Brownmiller, 1975; Schelong, 1994; Yllö, 2016). Thus, rape in marriage was perceived to be as impossible as a husband robbing himself. Early rape laws were enacted to protect men's property interests. For a long time, the complainant was hence either the family or father of an unmarried woman, or the husband of a married woman (Niemi-Kiesiläinen, 2000).

Second, until the modernisation of marriage acts in the early 20th century, a wife was not considered to be a competent legal person within the Western legal tradition. Generally, after entering into a marriage, husband and wife were seen to 'become one'. Due to women's societal and legal position, however, this meant that a wife's legal person was subsumed within that of her husband 
(Pylkkänen, 2009). The idea of marriage as a unity was justified as a way of protecting a harmonious symbiosis within the family; yet in practice, this continued to legitimise husbands' control over their wives (Schelong, 1994).

The third justification relates to the idea of marriage as a contract, and the subsequent interpretation that entering into a marital contract presupposes consent to fulfil a husband's sexual demands under any circumstances (Pateman, 1980; Russel, 1982). The intertwining of the common legal definition of rape as sexual intercourse without the consent of the victim and the idea of continuous marital consent has had a considerable effect on how legally and socially unimaginable rape by a husband has been in many countries until the last decades of the 20th century.

Socio-legal studies on more recent debates concerning marital exemption have shown that the retention of the exemption is often justified by appealing to various ominous scenarios, commonly related to wives' alleged vindictive misuse of rape charges or from difficulties in providing evidence (e.g. Brooks, 1989). But these debates also demonstrate the long-reaching effect of the historical and cultural understandings of marriage discussed above. For example, Mandal (2014) has pointed out that the protection of marriage as a culturally unique and valuable institution was a key concern in India in 2013 when, despite intense debate, the marital exemption was not repealed. Moreover, the understanding that marital rape is not real rape - and thus should be addressed by measures that are considered more suitable, given the private and intimate context - is a widely used justification for retaining the marital exemption and is also firmly connected to historical understandings of marriage (e.g. Williamson, 2017).

From a wider perspective, the historical impact has not been restricted to legislation or wives' sexual autonomy. Because of the presumption of irrevocable marital consent, the courts have used previous (or even potential) consensual sexual intercourse in other contexts, such as current or former intimate partners, cohabitees, or dates, as evidence of ongoing consent, hence making sexual violence accepted or less condemned and the victim less credible (e.g. Jokila, 2010; Lazar, 2010).

\section{Data and method}

The following sections provide an empirical analysis of two legislative processes related to the criminalisation of rape within marriage in Finland. The data were collected as part of a broader study (Kotanen, 2013) and comprise primary and secondary data sets. The primary data set contains all legislative documents from two legal processes: (1) the unsuccessful proposal to criminalise rape within marriage between 1965 and 1970 and (2) the criminalisation of rape within marriage between 1991 and 1994.

Despite the more than two decades that elapsed between the processes analysed in this chapter, the legal procedure for enacting legislation was very similar. In Finland, a governmental proposal (GP), which represents the key document of 
a legislative process, is prepared by Ministry of Justice officials and generally provides an account of the present state of the legislation in question; GPs typically also include an international overview. The proposed legislative revision, its importance, aims and desired effects of implementation are also justified in GPs. The largest difference in terms of the procedure and the documents produced during it is related to the GPs' preparatory process that took place before the proposals were passed to Parliament. In the first process, the GP 52/1970 was based on two preparatory documents: the report of the Committee of Sex Crimes (CSC report 1967: A12) and the Statement of the Supreme Court (SSC, 1969) for the CSC's report. The second process proceeded in two phases: Members of Parliament (MPs) put forward two legislative initiatives (25/1991 and 28/1991) in 1991 , which were handled in subsequent parliamentary hearings. During the following two years, Ministry of Justice officials formed the latter initiative into a GP 365/1992, which they then handed to Parliament in early 1993.

In addition to the above-mentioned documents prepared for GPs, the legislative material includes documents related to the following legislative work of Parliament presented with the GP, including committee reports, written expert statements from committee hearings ${ }^{2}$ and transcriptions of the plenum discussions of Parliament. The legislative data covered in the present study amount to 205 pages.

In order to trace the interaction between law and societal values related to the criminalisation of rape in marriage, a secondary data set was collected to supplement the legislative data. This data set consists of all news articles on IPV published in the largest Finnish newspaper in terms of circulation, Helsingin Sanomat (HS), between 1990 and 1994. In addition, the secondary data include all available written materials related to campaigns and initiatives against IPV by different social actors and government organisations during the same timeframe. The secondary data consist of approximately 450 pages. It is important to note, however, that most documents in the secondary data relate to the latter legislative process, mainly because of the lack of public debate about rape in marriage in the late $1960 \mathrm{~s}$.

The focus of the current qualitative analysis is on legal and social change, and their mutual dynamics, in relation to wives' sexual autonomy. The starting point of the analysis is the Finnish legal historian Anu Pylkkänen's (2009, p. 19) notion that the law has never actually offered protection for women as 'owners of their selves'; instead of integrity, the perspective of the legal regulation of institutions and relations has often been based on the protection of other values, such as economic interests and societal morals. Neither legislative documents nor their ultimate outcomes - legal statutes - are disconnected from the society they are legislated for. Despite the pursuit of neutral objectivity, legal norms and extralegal values tend to interact and intermingle, particularly with topics such as sexuality, reproduction, family issues and personal integrity (Pylkkänen, 2009). As Ngaire Naffine (2007) has stated, the dominant understandings of rape, often implicitly presented as universal and natural, are constructed on a heterosexual male conception of sexuality rather than on women's perceptions and experiences. This becomes visible not only in historical understandings, such 
as the supposed impossibility of raping an unchaste woman, but also more currently in discussions of whether qualifications of rape as a crime should be based on the lack of consent rather than the use of violence or the threat of violence.

The two legal processes analysed in this chapter represent potential moments of legal change. Keeping in mind the intertwining and interacting of legal and social values and understandings, the documents of the legislative data are perceived as a negotiation through which legally and socially acceptable sexuality and sexual acts are defined and through which sexual autonomy is either granted, restricted or denied. The secondary data capture some of the key moments of the social change that has taken place outside the legal realm. The data thus enable the locating of legislators' actions in a wider context: for example, by tracing the moments, measures and/or groups that created pressure for legal change.

The analysis focusses on the justifications provided for the proposed enactment during the legal processes, for example, by examining what kinds of protected interests and societal values these justifications entailed, or what kinds of legal or extralegal understandings of sexuality, marriage and rape as a crime these justifications were based on. Moreover, how the justifications, and the values and interests connected to them, assumed or denied wives' sexual autonomy. The focus is not just on the change in legislation and society but also on the resistance to the change, particularly in the first legal process. A specific point of interest is whether the change, or resistance to it, seems to have been connected to legal culture and tradition or to the wider societal environment. Pylkkänen (2009) has argued that even though the law typically describes the history of winners, spaces of resistance and challenge are always to be found, and that it is equally important to pay attention to the silences: the lack of voices and any unexplained breaks in legal reasoning and conceptualisation. Following this, the present analysis also aims to pinpoint possible missing perspectives and speaks to these silences.

\section{Sexual autonomy in Finnish legislation in the late 1960s: husband's right, wife's duty}

The sexual norms that guided the legal regulation of sex crimes in the 19th century were largely based on religious understandings and beliefs. Accepted and chaste sexual activity was legally and socially institutionalised within the confines of marriage and procreation. This understanding was gradually abandoned during the early 20th century. For example, illicit intercourse was decriminalised in 1926 in Finland, followed by adultery in 1948. Despite the modernisation of the legal regulation of marriage and the repeal of these statutes, when preparations for the revision process began in the mid-1960s, Finnish law on sex crimes was still mainly based on religious-led sexual morals; the legislation on 'chastity crimes" ${ }^{3}$ that was in force at the time had been enacted in 1889. According to the law, forced sexual intercourse could only be interpreted as rape if the perpetrator had been someone other than the husband of the particular woman. A husband could 
only be charged for raping his own wife if he had aided and abetted another man in committing the act. In theory, other statutes, which regulated physical violence instead of sex crimes, allowed for a husband who had committed an act equivalent to rape against his wife to be charged for an assault or coercion. The penal scales for both offences were considerably more lenient compared to rape. ${ }^{4}$

While Sweden and Denmark had abolished marital exemptions in the 1960s, other European countries did not proceed with the matter despite the activity of second-wave feminists. Although social activism for women's rights and gender equality began in Finland later than in the Anglo-Saxon countries and the other Nordic countries, there was emerging activism for sexual liberation and reproductive rights for women as part of protests against restricting sexual norms and gendered double standards (Julkunen, 2010). This activism was connected to a critical, yet somewhat gender-neutral, organisation called Yhdistys 9. ${ }^{5}$ Within the organisation, both women and men campaigned for equality; their actions led to the establishment of the governmental Advisory Board for Equality (TANE ${ }^{6}$ ) in 1972.

In general, contemporary legal scholars considered the legal position of men and women to be fairly equal, even though it was acknowledged that the legislation still consisted of certain unequal statutes. For example, it was criticised that a wife was obliged to take her husband's surname upon marriage under Finnish law (Mickwitz, von Essen \& Nordgren, 2008). None of the deficiencies highlighted at the time were related to women's physical or sexual integrity; instead, questions related to economic and labour rights were the priority. While this was a joint Nordic blind spot, one specific reason for the invisibility of physical and sexual integrity, particularly in Finland, has been the comparatively late modernisation of Finnish legislation and society that has hindered the acknowledgement of individual rights (Pylkkänen, 2009). The shift from an agrarian society to a Nordic welfare state was largely delayed due to the destructive wars in the earlier half of the last century. From the legal perspective, apart from the protection of property and rights related to ownership, fundamental rights were largely absent in Finnish legal discussions before the 1970s (Pylkkänen, 2012). The first actual listing of fundamental rights was introduced only in 1995 after a long revision process of the constitution. The Nordic culture of sameness, and the tendency to avoid open conflict between genders, has also been particularly strong in Finland. One indicator of this was the channelling of social activism through Yhdistys 9 rather than through a women's movement (Jallinoja, 1983).

The preparatory work for the new Sex Crime Act began in December 1966, when the Finnish government appointed the Committee of Sex Crimes. After a year, the CSC handed its report to the government which then requested a statement from the Supreme Court. Following the Supreme Court's suggestions, the report was revised by Ministry of Justice officials into GP 52/1970, which was eventually handed to Parliament in 1970. The CSC report (1967: A12) stated that the current criminal justice system was based on conceptions connected to religiously based morality, and hence heterosexual marriage had 


\section{Riikka Kotanen}

been seen as the only lawful context for sexual relations. However, the CSC estimated in its report that during the 20th century, gender equality had developed to the point that 'almost all differences between the genders have disappeared within society'. This highlights how long-lived the Nordic ethos of 'already-achieved equality' is.

The general justifications for the revision of the regulation of sex crimes represented a clear separation from the previous regulation. In other words, instead of protecting chastity and other religious-based moral sentiments related to sex and sexuality, the focus of the justifications was on the protection of individual autonomy, especially in situations where one's autonomy had been denied due to 'intimidation or violence'. According to the report (CSC 1967: A12), instead of protecting only sexual morals and the chastity of society, the Criminal Law should prioritise the protection of individual autonomy. The CSC utilised the revised Swedish Sex Crime Act from 1962, which included the criminalisation of rape in marriage, as a model for its proposal. The Swedish example was also one of the key justifications for initiating the criminalisation of marital rape in Finland. Despite proposing the removal of the marital exemption, the CSC's attitude towards the potential criminalisation remained ambivalent. In its report, the modern idea about individual autonomy as the core protected interest of law was intermingled with the understanding that marriage was meant to provide ongoing consent:

... marriage can no longer be considered to establish sexual authority for a husband over his wife; sexual intercourse requires mutual consent even within a marriage: although getting married justifies an assumption that such consent has been given.

(CSC, 1967: A12)

The Supreme Court was solicited for a written statement to the committee's report. In its statement (SSC, 1969), the Supreme Court opposed the proposal for criminalising rape in marriage. It was considered too modern and unsuitable for Finland (Kotanen, 2013). When GP 52/1970 was finally handed to Parliament, the Supreme Court's position was straightforwardly adopted into the proposal. Several justifications, such as that 'criminalisation would be against the Finnish people's sense of justice', were replicated word for word from the Supreme Court's statement.

The most significant impediments to criminalisation found in the data are (1) the denial and questioning of the occurrence of marital rapes, (2) the conceptual inextricability of marriage and sexual intercourse, and (3) the definition of rape as a chastity crime in the legislation (in force at the time) and governmental proposal. The justification for the opposition to criminalisation referred to the conception that such acts are not committed 'in practice between spouses living in a normal marriage', and also the possible harm was assessed as being so minor that it did not require any intervention. Marriage and sexual intercourse were connected to each other so closely in the legal documents that they appear 
indivisible. Only two addresses held in Parliamentary hearings challenged the 'marital duties' of a wife to resign herself to sexual intercourse with her husband, even against her will. These addresses represented modern ideas about gender equality and women's human rights, which were more characteristic of the latter part of the data. In them, wives were also acknowledged as victims of sexual violence - a perspective that is missing elsewhere in the data from the 1960s (Kotanen, 2013).

Even though the marital exemption is explicitly relational by definition, in the data, the exemption also has spatial restrictions. According to GP 52/1970 and the Supreme Court's statement (SSC, 1969), wives' marital duties will cease only in cases where spouses are separated due to an approaching divorce. Only living in separate households is considered a sufficient indicator for the withdrawal of ongoing consent. The Supreme Court's statement highlights the discontinuation of sexual duties due to physical and spatial separation. The withdrawal of the marital exemption is justified because merely forcing oneself into another person's private sphere is a criminal offence in such situations. The interpretation of who a specific space belongs to thus becomes an important qualifier of rape. From a spatial perspective, the private sphere becomes a protector of wives' sexual autonomy:

In cases of separation, one cannot assume without question that consent to sexual intercourse related to marriage would exist. ... It would be unfair to exclude wives from legal protection in these cases ...

(SSC, 1969)

Discussion about how the section on sexual crimes should be named within the Criminal Act illustrated how firmly rooted religiously based sexual morality and conservative attitudes remained in the late 1960s in the context of Finnish legislation. The CSC suggested that the heading of the particular section should be updated from 'Chastity crimes' to 'Sex crimes', which it regarded as more suitable and modern. The Supreme Court opposed this proposal and this was adopted into GP 52/1970. The understanding of rape, and other sex crimes, as unchaste is one of the key explanations for the incongruity of marriage and rape. From the point of view of marital rape, this understanding proved to be a significant obstacle to its criminalisation. According to these two documents, a chastity-crime charge would be 'inappropriate' and 'shameful' in the context of marriage. Classifying marital intercourse as a crime against sexual morals and chastity would thus be impossible, as doing so would be contradictory to the idea of marriage as the only legitimate context for intercourse. In the data, this contradiction was regarded as so significant that not even the most grievous violation of a wife's sexual autonomy could be considered to be penalised as a chastity crime, as that would imply that these acts, and consequently the marriage they were committed within, were immoral: 
In other cases [i.e. when spouses are not separated], not even sexual acts that violate the autonomy and freedom of the other spouse in an aggravated manner should be penalised as chastity crimes ...

(SSC, 1969)

The quote above is important from two perspectives. First, its gender-neutral articulation, particularly in a legal context where rape can only be inflicted on a woman, is a good example of the tendency to downplay gender differences. Second, the quote reveals how inconsistent and contradictory attitudes towards marital rape were at the time. The same action is defined within one sentence, first, neutrally as a sexual act, and immediately after as a gross violation of rights. The statement hence seems to include a clear awareness of the problematic nature of, and the possibly serious consequences connected to, rapes inflicted on wives. Nevertheless, wives' sexual autonomy was consciously defined more narrowly in comparison to other women; within marriage, sexual autonomy was seen specifically as the right of the husband.

In the late1960s, the violation of a woman's sexual autonomy qualified as a crime only if the act could be interpreted as unchaste; in other words, if it simultaneously violated conservative, religion-based sexual morals. Since forced intercourse with one's own wife was not regarded as such a violation at the time, these moral norms were, in practice, more valued as an interest of legal protection than was married women's sexual autonomy. Moreover, the idea of a woman's ongoing consent was not applied only to married women in subsequent criminal law enactment. Other types of relationships between 'the offender and the woman' were also considered as extenuating circumstances, and thus a possible remission of sentence. This view was not questioned at all in the data. However, in addition to the CSC's original suggestion to remove the marital exemption, the close result of the parliamentary vote -77 in favour versus 86 opposed to criminalisation - implies that the legal and social understandings of marital rape had already started to diverge.

\section{Criminalising rape in marriage in 1994: in defence of equality}

The understandings attached to rape slowly began to change in Western countries from the 1970s onwards. Anglo-American feminist activists, followed by feminist researchers, were at the forefront of raising awareness about rape as a social and structural problem by emphasising the position and rights of victims (e.g. Millet, 1970; Connel \& Wilson, 1974). Instead of involuntary sex, rape was defined not just as a crime but as an exercise of gendered power (Brownmiller, 1975). General attitudes towards marital rape, however, did not change considerably until the late 1980s and early 1990s (Gavey, 2005). The United Nations General Assembly adopted the Convention on the Elimination of All Forms of Discrimination against Women (CEDAW) in 1979, which was instituted in 1981. Internationally, the UN and CEDAW had an important role in expediting legislative changes on marital rape in Europe in the late 1980s and early 1990s (Utriainen, 2010; van Leeuwen, 2013). 
In Finland, marital rape was publicly acknowledged after it became the subject of critical attention in the late 1970s as part of the book Violence within Marriage (Germain et al., 1978). Nevertheless, no legislative initiatives were undertaken for criminalisation until the early 1990s, even though the social atmosphere and attitudes had changed considerably in Finland during these two decades. International obligations spurred on gender equality and the legitimation of women's rights; for example, the first Equality Act (609/1986) was enacted in 1986 largely due to legal preparations for the pending ratification of CEDAW. The status of marriage as an institution had begun to diminish from the 1970s, and societal changes influenced attitudes to marital rape. According to a survey published in 1993 , only $10 \%$ of men and $8 \%$ of women were in favour of the idea that rape should be punished differently when committed within marriage (Haavio-Mannila \& Kontula, 1993). Still, in the early 1990s, Finland remained among the few Western countries not to have criminalised rape within marriage.

In this legislative process, the interaction of law and societal values occurs in the form of extralegal social activity and pressure directed towards legislators. The contradiction between the changed societal attitudes and the extant legislation induced critical public discussion. In particular, the members of TANE's recently established division of gendered violence actively promoted the cause against gendered violence (e.g. Sosiaali- ja terveysministeriö, 1991). It was not just the feminist activists who were raising critical awareness, however. For example, two editorials in Helsingin Sanomat pressed for the criminalisation of marital rape (HS 13.6.1991; HS 29.11.1991), and MPs prepared two separate legislative initiatives on criminalisation. The first initiative 25/1991 was made by a group of MPs who all were representatives of the Left Alliance. ${ }^{7}$ At the time, the initiative appeared rather radical in the Finnish context, suggesting not only criminalising rape in marriage but also, for example, subjecting assault in the private sphere to public prosecution as well as a change in the legal definition of rape to redefine it as gender-neutral regarding rape victims. ${ }^{8}$ The second legal initiative 28/1991 was signed by a group of MPs from several political parties; the initiative's more moderate aim was to criminalise marital rape by removing the marital exemption and eliminating from the statute the sentence defining the relationship between the offender and victim as a possible mitigating circumstance.

After Parliamentary hearings addressed the initiatives, the cause progressed slowly. According to Pirjo Pehkonen (2003), who has analysed anti-violence activism within the Finnish women's movement, members of TANE who actively worked to promote the cause pointed out that there was clear reluctance on the part of the Ministry of Justice to make any progress in the matter. However, the TANE members eventually managed to convince the then Minister of Justice of the importance of criminalisation. GP 365/1992, based on the latter legal initiative 28/1991, was handed to Parliament in January 1993. Similar reluctance by the Ministry of Justice also appeared later in the 1990 s in relation to the increasing demands for legal regulation of 


\section{Riikka Kotanen}

IPV. For example, for several years before the enactment of legislation to introduce the restraining order in 1998, feminist activists, the media and MPs had pressured the Ministry of Justice to act (Kotanen, 2018). The ministry's reluctance seems to have been based largely on a lack of recognition of the scale and prevalence of IPV as well as an understanding that such violence was a problem of social rather than criminal justice policy (NiemiKiesiläinen, 2004; Kotanen, 2013).

In GP 365/1992, the explicit justification for legislative alterations was to strengthen the individual's right to sexual integrity and autonomy. A closer analysis of the data, however, shows that sexual autonomy was not the only protected interest: such autonomy was only one of several elements of equality, which was the key interest to be protected. This was particularly related to the Parliamentary hearings. In their addresses, the MPs presented Finnish equality as incomplete, particularly due to the marital exemption, as though the Criminal Law was calling Finnish equality into question. The proposed legal changes would provide a means for rectifying the situation and pursuing more comprehensive equality within legislation and society. Equality has three dimensions in the data: (1) equality between spouses, (2) equality among women, and more generally, (3) equality between genders.

This initiative is aimed as a part of actions to promote gender equality.

... The aim has been, as it has been in the legislation in general, to increase equality between spouses, and their independent right to decide whether to stay married or to end the marriage has been vitally reasserted .... The alteration of this statute is important, above all, with respect to principles.

(GP 365/1992)

Particularly in GP 365/1992, prepared by the Ministry of Justice, criminalisation appears as a 'principled revision'; in other words, as a legislative alteration whose importance lies in its principles. This is consistent with the lack of references to the real people who are affected by marital rape despite the research and statistics that by then had provided substantial information about these acts. In terms of missing perspectives, neither victims of rape nor offenders are mentioned at all in the GP.

The most weighty and concrete motivations for criminalisation are the international demands and agreements connected to Finland's approaching EU membership. Finnish feminist researchers have pointed out that the international agreements, as well as EU membership in general, have been the most significant reasons for promoting women's rights in Finland, particularly in terms of gendered violence (Kantola, 2006; Nousiainen \& Pentikäinen, 2013). In the GP, however, the binding force of these agreements is explicitly defined as having an effect 'in principle': 
The assembly [against violence towards women consisted of 16 ministers from Western European countries] passed a declaration that was signed by Finland ... in April 1991. In terms of legislation, the declaration states that physical violence against women is a crime within and outside marriage ... and that, in principle, physical and sexual violence has to be punished as severely when it is committed within marriage ...

(GP 365/1992)

In addition to the international agreements, another tangible international motivation for criminalisation was Finland's international reputation, especially vis-à-vis other Nordic countries and EU member countries. GP 365/1992 includes a comprehensive cross-European legal review in terms of marital rape. The partial revision, limited to the one statute that included the marital exemption, was validated by the pressure created by the European example in the situation where comprehensive revision of the Criminal Act was already in progress. The MPs emphasised in the Parliamentary hearings how harmful the current situation was to Finland's reputation. They highlighted criminalisation as an advantage not just for women but especially for Finland as a nation:

... we are enacting this [statute] separately so that we are not the only Western European country ... to not fulfil the international agreements we have concluded in this respect. This is the reason for handing this partial revision over to Parliament.

(Minister of Justice in a parliamentary hearing, 16 February1993)

Framing the criminalisation of marital rape as a national question of Finland's international image is not entirely exceptional. Highlighting gender-neutral national interests, such as the national economy, labour policy, or public health, has been a tradition in Finland within legal revisions for improving the societal position of women. This has been interpreted as a national strategy to avoid open conflict between genders (Rantalaiho, 1994; Julkunen, 2010). A marginal group of male MPs displayed an objection to criminalisation during the Parliamentary hearings; their addresses defended values based on the conservative sexual morals that dominated legal discussion in the 1960s (Kotanen, 2013). Similarly to other countries, they justified retaining the marital exemption through a presumption of potential misuse (e.g. Mandal, 2014; Williamson, 2017).

\section{Discussion}

The purpose of this study was to analyse justifications for the late criminalisation of marital rape in Finland by asking (1) how and why wives' sexual autonomy was rejected in the early 1970s, (2) what motivated the later criminalisation of marital rape in 1994 and (3) what kind of role the interaction between law and wider societal values played during the legal processes analysed in this chapter. The analysis has examined what kinds of legal or 
extralegal values, as well as understandings of sexuality, marriage and rape as a crime, these justifications were based on.

When the joint Nordic reform of marriage acts took place in the 1920s, the equalisation of marriage at the expense of religious views provoked more opposition in Finland than in the other Nordic countries due to Finland's conservative normative climate (Melby et al., 2006). According to the present study, conservative views still held a strong hold in the legal realm of marriage four decades later. The key justifications for the decision not to repeal the marital exemption were a mixture of historical understandings of marriage as a husband-led unity and as ongoing sexual consent on the part of the wife, combined with religiousbased moral views that mainly protected the moral reputation of marriage as an institution. Sexuality appears as a husband's right, a privilege guaranteed by his wife's marital agreement. From the female perspective, sexuality is a submissive duty. Wives' sexual autonomy is weighed against the chastity of marriage, which becomes crystallised in a conflict between the contemporary understanding of rape as an unchaste act and marriage as the solely appropriate and legitimate unity, even in cases of sexual violence.

The strong resistance to change within the legal realm highlights how inappropriate and alien the initiative, inspired by other Nordic countries, was seen in Finland. In some respects, this reflects Indians' objection to repealing the marital exemption; Mandal (2014) refers to this type of situation as 'cultural nationalism'. Marriage as an institution was perceived as a culturally unique part of society's morality, whereas the criminalisation of marital rape represented something that came from outside the familiar, cultural values. The prioritisation of conservative views, in terms of marriage as an institution, and the acceptance of wives' lack of sexual autonomy are particularly striking because, at the time, the Nordic countries had a well-established tradition of mutually revising and harmonising their legislation. One reason that the resistance to the change appeared fairly unanimous was the lack of social debate about the issue. Although sexual double standards were criticised, sexual integrity was not yet on the agenda (Pylkkänen, 2009). The close parliamentary vote, however, indicated that despite the silence and lack of discussion in the social and legal contexts, many considered the unequal position of wives to be unjust.

In the early 1990s, the change arose mainly through extralegal social activity aiming to bring the legal understanding of equality in line with societal understanding. Contrary to the situation in the late 1960 s, criminal law, and the old-fashioned and unequal values it embodied in terms of the regulation of sex crimes, were widely perceived as alien. They uncomfortably challenged something socially and culturally important: that is, the myth of equality (cf. Nousiainen \& NiemiKiesiläinen, 2001). In general, sexuality was only incidentally touched upon, and when it was, sexuality appeared as an equal right of men and women. Similarly to the late 1960s, resistance to change occurred on the part of legislators. The Ministry of Justice's reluctance hindered the legal process; they were later primarily motivated by the demands of Finland's recent EU membership.

The Nordic way of downplaying gender differences appeared in the 1990s as a calculated, traditional way of political argumentation for women's rights in 
Finland (cf. Rantalaiho, 1994; Julkunen, 2010). But this tendency to downplay was also a probable cause for the invisibility of female victims of sexual violence as well as the male perpetrators in GP 365/1992, the key document of the legal process. This tendency also presents an interesting contrast to the feminist social activism towards violence against women that started at the beginning of the 1990s, which was the main domestic motivation behind the legal change that consequently launched a wider process of legal reforms, particularly in relation to IPV (e.g. Kotanen, 2013, 2018). In general, however, this feminist redefinition of gender-neutral domestic violence to gender-based violence clearly had some influence on legal argumentation at the time.

The legal regulation of sexual crimes has been reformed in Finland on multiple occasions after revoking the marital exemption. The Act on Sexual Crimes was completely revised in 1999 to reinforce victims' individual autonomy and sexual self-determination as the main objects of protection. After a critical social debate and intensive campaigning by the Finnish section of Amnesty International, the legislative subsections on rape were further revised in 2011 and 2014 by widening the range of the punishability of rape (Kotanen \& Kronsteadt, 2019). As of 2019, legislators are yet again under extralegal pressure to change the Act on Sex Crimes following Sweden's 2018 reform. The citizens' initiative called 'Suostumus2018,9 demands that the current definition of rape, based on the use of physical force or the threat of violence, be changed to one based on lack of consent.

\section{Notes}

1 Different countries have criminalised rape in marriage either by changing the legislation regulating sex crimes or by changing the judicial customs, such that these acts are dealt with in courts in a similar manner to rape committed outside marriage.

2 The expert statements related to the attempt to criminalise rape in marriage in the late 1960 s were not as comprehensively documented in literal form as the expert statements in the early 1990s and hence offer very little additional information.

3 All quotes from the research data have been translated from Finnish to English by the author.

4 At the time, the maximum sentence for rape was 10 years in prison, while the maximum penalties for assault and coercion were two years and one year, respectively. The maximum penalty was a fine for cases of minor assaults.

5 'Association 9' in English.

6 From the Finnish for Tasa-arvoasiain neuvottelukunta.

7 A left-wing political party in Finland.

8 According to the legislation in force in 1991, rape could only be inflicted on women.

9 'Consent 2018' in English; see http://suostumus2018.fi/.

\section{References}

Black, M., Basile, K., Breiding, M., Smith, S., Walters, M., Merrick, M., ... Stevens, M. (2011). The National Intimate Partner and Sexual Violence Survey: 2010 summary report. Atlanta: National Center for Injury Prevention and Control.

Brooks, R. (1989). Marital consent in rape. Criminal Law Review, 877-887. 


\section{Riikka Kotanen}

Brownmiller, S. (1975). Against our will: Men, women, and rape. New York: Bantam Books.

Connel, N., \& Wilson, C. (1974). Rape: The first sourcebook for women by New York radical feminists. New York: New American Library.

Finkelhorn, D., \& Yllö, K. (1985). License to rape: Sexual abuse of wives. New York: The Free Press.

Gavey, N. (2005). Just sex? The cultural scaffolding of rape. New York: Routledge.

Germain, S., Mattila, K., Polkunen-Gartz, M.-L., \& Törnroth, C. (1978). Väkivalta avioliitossa. Helsinki: Tammi.

Haavio-Mannila, E., \& Kontula, O. (1993). Seksuaalinen lähentely, ahdistelu ja maksettu seksi. In O. Kontula \& E. Haavio-Mannila (Eds.), Suomalainen seksi: Tietoa suomalaisten sukupuolielämän muutoksesta (pp. 311-342). Porvoo, Finland: WSOY.

Hernes, H. M. (Ed.). (1987). Welfare state and women power: Essays in state feminism. Oslo: Norwegian University Press.

Jallinoja, R. (1983). Suomalaisen naisasialiikkeen taistelun kaudet. Juva, Finland: WSOY.

Jokila, H. (2010). Tahdonvastainen suostumus ja liiallisen luottamuksen hinta: Raiskauksen ja muiden seksuaalirikosten oikeudellisen tiedon konstruktiot. Helsinki: Suomalainen lakimiesyhdistys.

Julkunen, R. (2010). Sukupuolen järjestykset ja tasa-arvon paradoksit. Tampere, Finland: Vastapaino.

Kantola, J. (2006). Feminists theorize the state. Basingstoke, UK: Palgrave Macmillan.

Kotanen, R. (2010). Omistussuhteesta autonomiaan? Raiskauksen kriminalisoiminen avioliitossa ja aviovaimon seksuaalinen itsemääräämisoikeus Suomessa. Oikeus, 4, 369-395.

Kotanen, R. (2013). Näkymättömästä näkökulmaksi - Parisuhdeväkivallan uhrit ja oikeudellisen sääntelyn muutos Suomessa. Helsinki: Unigrafia.

Kotanen, R. (2018). The rise of the crime victim and punitive policies? Changes to the legal regulation of intimate partner violence in Finland. Violence against Women, 24 (12), 1433-1453.

Kotanen, R., \& Kronsteadt, J. (2019). Attribution of responsibility for sexual crimes beyond individual actors - Construction of responsibility of offenders, victims and society in laypersons' explanations. International Review of Victimology, 25(3), $358-374$.

Lazar, R. (2010). Negotiating sex: The legal construct of consent in cases of wife rape in Ontario, Canada. Canadian Journal of Women and the Law, 22(2), 329-363.

Mandal, S. (2014). The impossibility of marital rape. Australian Feminist Studies, 29(81), 255-272.

Melby, K., Pylkkänen, A., Rosenbeck, B., \& Carlsson Wetterberg, C. (2006). The Nordic model of marriage. Women's History Review, 15(4), 651-661.

Mickwitz, M., von Essen, A., \& Nordgren, E. (2008). Roolien murtajat: Tasaarvokeskustelua 1960-luvulta 2000-luvulle. Helsinki: Gaudeamus.

Millet, K. (1970). Sexual politics. New York: Doubleday.

Naffine, N. (2007). Feminism \& criminology. Cambridge, UK: Polity Press.

Niemi-Kiesiläinen, J. (2000). Mitä seksuaalirikoslailla halutaan suojella? In P. Honkatukia, J. Niemi-Kiesiläinen, \& S. Näre (Eds.), Lähentelyistä raiskauksiin: Tyttöjen kokemuksia häirinnästä ja seksuaalisesta väkivallasta (pp. 137-168). Helsinki: Nuorisotutkimuseura.

Niemi-Kiesiläinen, J. (2004). Rikosprosessi ja parisuhdeväkivalta. Helsinki: WSOY.

Nousiainen, K., \& Niemi-Kiesiläinen, J. (2001). Introductory remarks on Nordic law and gender identities. In K. Nousiainen, Å. Gunnarsson, K. Lundström, \& J. Niemi-Kiesiläinen 
(Eds.), Responsible selves. Women in the Nordic legal culture (pp. 1-22). Aldershot, UK: Ashgate.

Nousiainen, K., \& Pentikäinen, M. (2013). Rise and fall of the CEDAW in Finland: Time to reclaim its impetus. In A. Hellum \& H. Aasen (Eds.), Women's human rights: CEDAW in international, regional and national law (pp. 557-587). Cambridge, UK: Cambridge University Press.

Pateman, C. (1980). Women and consent. Political Theory, 2, 149-168.

Pehkonen, P. (2003). Naisen puolesta, ei miestä vastaan: Suomalainen naisliike väkivaltaa vastustamassa. Joensuu, Finland: Joensuun yliopisto.

Pylkkänen, A. (2009). Trapped in equality: Women as legal persons in the modernisation of Finnish law. Helsinki: Finnish Literature Society.

Pylkkänen, A. (2012). Muodollisen tasa-arvon pitkä historia ja sen sisäänrakennetut erot. In J. Kantola, K. Nousiainen, \& M. Saari (Eds.), Tasa-arvo toisin nähtynä (pp. 57-72). Helsinki: Gaudeamus.

Rantalaiho, L. (1994). Sukupuolisopimus ja Suomen malli. In A. Anttonen, L. Henriksson \& R. Nätkin (Eds.), Naisten hyvinvointivaltio (pp. 9-30). Tampere: Finland: Vastapaino.

Russel, D. (1982). Rape in marriage. Bloomington: Indiana University Press.

Schelong, C. (1994). Domestic violence and the state: Responses to and rationales for spousal bettering, marital rape and stalking. Marquette Law Review, 1, 79-120.

Sosiaali- ja terveysministeriö. (1991). Tasa-arvojulkaisuja 1/1991: Naisiin kohdistuva väkivalta. Helsinki: Sosiaali- ja terveysministeriö.

UN Women. (2011). Progress of the world's women 2011-2012: In pursuit of justice. New York: UN Women.

Utriainen, T. (2010). Raiskaus rikosoikeudellisena ongelmana. Rovaniemi, Finland: Lapin yliopistopaino.

van Leeuwen, F. (2013). Women's rights are human rights! In A. Hellum \& H. Aasen (Eds.), Women's human rights: CEDAW in international, regional and national law (pp. 242-267). Cambridge, UK: Cambridge University Press.

Williamson, A. (2017). The law and politics of marital rape in England and Wales 1945-1994. Women's History Review, 26(3), 382-413.

Yllö, K. (2016). Prologue: Understanding marital rape in global context. In K. Yllö \& M. Torres (Eds.), Marital rape: Consent, marriage, and social change in global context (pp. 1-8). Oxford, UK and New York: Oxford University Press.

\section{Original sources}

Eduskunnan täysistuntokeskustelu HE 365/1992 Hallituksen esitys eduskunnalle laiksi rikoslain väkisinmakaamista ja vapautta loukkaavaa haureutta koskevien säännösten muuttamisesta, 16.2.1993. (Parliamentary hearing, 16 February 1993).

HE 52/1970 vp Hallituksen esitys eduskunnalle siveellisyyteen kohdistuvien rikosten rangaistuksia koskevan lainsäädännön uudistamisesta. (Governmental proposal [GP] 52/1970).

HE 365/1992 vp Hallituksen esitys eduskunnalle laiksi rikoslain väkisinmakaamista ja vapautta loukkaavaa haureutta koskevien säännösten muuttamisesta. (Governmental proposal [GP] 365/1992).

Helsingin Sanomat, 13 June 1991, editorial: ‘Synkän kolkko suomalainen avioliitto'. Helsingin Sanomat, 29 November 1991, editorial: ‘Avioraiskauksestakin rikos'. 


\section{Riikka Kotanen}

KM 1967: A12. Seksuaalirikoskomitean mietintö. Helsinki 1968. (Report of the Committee of Sex Crimes [CSC] 1967: A12)

Korkeimman oikeuden lausunto ehdotuksesta hallituksen esitykseksi eduskunnalle siveellisyyteen kohdistuvien rikosten rangaistuksia koskevan lainsäädännön uudistamisesta. Selostuksia ja tiedonantoja Korkeimman oikeuden ratkaisuista vuonna 1969. Helsinki, 1970. (Statement of the Supreme Court [SSC] 1969)

LA 25/1991 vp Ehdotukset laeiksi rikoslain 20 ja 21 luvun sekä maksuttomasta oikeudenkäynnistä annetun lain 1 §: n muuttamisesta. (Legal initiative[LI] 25/ 1991).

LA 28/1991 vp Ehdotus laiksi rikoslain 20 luvun muuttamisesta. (Legal initiative [LI] 28/1991). Laki naisten ja miesten välisestä tasa-arvosta (609/1986). 